\title{
Theorizing College Governance across Epistemic Differences: Awareness Contexts of College Administrators and Faculty
}

\author{
Linda Muzzin \\ Ontario Institute for Studies in Education, University of Toronto
}

\begin{abstract}
Awareness contexts are useful concepts in symbolic interactionist research, which focusses on how everyday realities are constructed. To provide a fresh perspective on governance in Canada's colleges, I sorted vignettes in interview data collected from administrators and faculty into four types of contexts originally derived from observation of interaction between physicians and patients around bad news. These theoretical categories were introduced by Glaser and Strauss in their 1965 book Awareness of Dying. Applying this lens revealed a "closed awareness" context around college fund-raising and a "mutual suspicion" context in administrator-faculty interaction around student success policy. Examples of "mutual pretense" included feigned administrator-faculty cooperation around changing college missions and faculty workload formulas. "Open awareness" or dialogue, however, occurred where professional bodies or unions intervened. Sorting by awareness contexts reveals similarities between doctor-patient and administrator-faculty interactions. For example, just as doctors feared that delivering bad news to patients might precipitate "mayhem" in the hospital, college administrators may fear that openness around divisive topics might precipitate "mayhem" in college management.
\end{abstract}

\section{Résumé}

Les contextes de prise de conscience constituent un élément essentiel de la rechercheen interactionnismesymbolique, dontl'objectifest desavoir élaborer des réalités au quotidien. En effet, afin d'obtenir une nouvelle perspective 
quant à la gouvernance des collèges universitaires au Canada, l'auteure trie les données tirées d'entrevues effectuées auprès d'administrateurs et de membres du corps enseignant, à partir de quatre types de contextes décrivant une interaction entre médecins et patients au sujet de la mort. Il faut savoir que Glaser et Strauss (1965) ont élaboré ces contextes théoriques dans leur livre Awareness of Dying. Le présent article propose un exemple de « contexte fermé de prise de conscience » (campagne de financement), un autre de "suspicion réciproque »(politique de réussite estudiantine), ainsi que des exemples de «faux-semblant mutuel » (coopération feinte entre administrateurs et corps enseignant quant au changement de mission du collège universitaire et aux formules d'attribution de charge de travail). Toutefois, la " prise de conscience ouverte ", ou dialogue, se produit lors d'interventions par des organismes professionnels ou des syndicats. Tous ces exemples révèlent des similitudes entre les interactions médecin-patient et administrateurs-corps enseignant. Ainsi, tout comme les médecins redoutaient que l'annonce d'une mauvaise nouvelle aux patients ne déclenche " une pagaille » à l'hôpital, les administrateurs de collèges universitaires craignent que s'exprimer ouvertement sur des questions controversées produise le même effet sur la gestion de l'institution.

\section{Introduction}

Glaser and Strauss' (1965) theory of "awareness contexts" (detailed below) was chosen as a way to frame the data collected in a national study of college faculty and administrative careers and everyday working experiences. Sorting their explanations by type of awareness context revealed divergent views between faculty and administrative constituencies in six areas, namely (1) funding, especially industry involvement in college finances; (2) policy around student success; (3) college mission; (4) faculty workload formulas; (5) the maintenance of quality in the construction and implementation of the curriculum; and (6) online teaching. These profound differences were theorized to occur at the ontological or epistemological level, rather than at an instrumental level at which they can be "talked through" and easily resolved. On the other hand, some colleges had been able to open dialogue on a few issues of governance led either by faculty in professional associations or by college unions.

Glaser and Strauss (1965), the founders of grounded theory methodology (GTM), used GTM to document and theorize the interactions between patients who were dying and their physicians. They identified four types of contexts: "closed awareness," in which the physician knew about the situation but the patient did not and no discussion about, for example, the process of dying occurred between the two; "mutual suspicion," in which the patient suspected he or she was dying and in which the physician suspected the patient knew, though neither discussed it directly; "mutual pretense," in which both knew the bad news but each pretended not to know and the two avoided discussion with each other about the situation; and "open awareness," in which open dialogue between the patient and the physician occurred. To provide a fresh perspective on college governance, this paper presents examples of each type of awareness context from the college study data. 


\section{Methods and Purpose}

The original goal of the study for which this data was collected was "to 'map' the articulation of college faculty teaching careers and everyday working experiences to the subtexts of curricula" in the trades and technology, business, human services, health, literacy and arts and science. ${ }^{1}$ Mapping followed Adele Clarke's (2005) complex "postmodern" version of grounded theory, ${ }^{2}$ which notes various elements as they emerge in data collection on what Clarke (p. 90) calls a "messy map." These elements are specific individual human actors/groups in the colleges, political/economic and temporal elements, major issues/debates, non-human/silent actors, discursive constructions of nonhuman actants, symbolic elements, spatial elements and related discourses. GTM was originally designed to generate theory inductively through an intensive coding exercise (Glaser \& Strauss, 1967). It grew out of an American and Canadian sociologically-based social psychology discipline (symbolic interactionism, or SI) which assumes that everyday meaning in social life arises from interaction among societal members (Haas \& Shaffir, 1978).

Using Clarke's version of GTM, texts such as transcripts of face-to-face interviews were coded and the results used to choose the next interviews. Choosing theoretically-relevant interviews (termed "theoretical sampling") enabled the researcher to select administrators who were in a position to comment on issues raised by faculty in this study, such as presidents in the area of funding. Data collection stops when the researcher determines that "saturation" is attained (that is, when no more new theory is being generated). When the epistemological chasm between administrators and faculty in this project was seen to appear across all the categories derived from GTM, the SI theory of "awareness contexts" was deemed relevant and mapped into the analysis. Classical SI would call awareness contexts a "generic social process" (Prus, 1987) that maintains social order in the face of threats to management of ongoing interactions. Because higher education is an applied field, scholars in the field may find this approach limited, since it does not lead to policy recommendations for addressing the epistemological chasm researched here. However, the approach explains how social order is brought about when norms are not shared, as was evident in many categories of this data.

Following the example of early Canadian college researchers (e.g. Dennison, 1995; Levin, Kater \& Wagoner, 2006), my co-researcher and I visited colleges in different provinces and interviewed faculty in each of the curriculum areas of interest. The study ran from 2006 to 2013, producing 320 face-to-face interviews conducted in all provinces and all programs of interest. This continual data collection was necessary to keep up with the constantly changing college faculty landscape. ${ }^{3}$

Approximately 70 of the 320 interviews were with administrators, who were sampled theoretically from among presidents and vice-presidents, heads, deans, principals, coordinators and union personnel. The transcripts of interviews comprised 8,000 pages and coded categories were organized into maps of the categories discussed in this paper (such as administrator-faculty relationships; faculty and administrator responsibility for program quality; college mission and branding; the politics of curriculum; governmentcollege relationships; faculty workload; student success policy and practice; and the role of industry in college affairs). Data collection was informed by critical theoretical perspectives that allowed the observation of how gender and race figured into the practice of governance, although these processes are not foregrounded in this particular analysis. 
Instead, responding to a call for papers on the complexities of postsecondary governance, I applied an already-researched SI theory about awareness contexts to examine the major epistemic split between administrators and faculty that runs through the entire data set.

The paper should be interpreted as synthesizing scores of examples of the phenomena of interest and then choosing clear situated examples to illustrate how administrators and their faculty deal with situations that range in scale and importance but which reveal quite different worlds of discourse and action. This analysis moves away from assumptions about causality or trajectory that were embedded in first-generation GTM. Classical versions of GTM warned researchers to avoid preconceived notions, but in this case, the application of the "awareness context" categories that arose from Glaser and Strauss' (1965) research fit; in both sets of relations, an epistemological "chasm" in thinking can be seen between the two sets of actors. The goal of this paper is to provide a first-level analysis of the application of this theory to the college data, exploring the difficult area of how social order is maintained in situations where actors do not share epistemological assumptions.

Confidentiality of both the college and the individuals was promised in both data collection and analysis. It is maintained here by grouping colleges by indicating only whether they were from Ontario or Quebec (approximately 100 interviews); the eastern provinces (another 100); or the western provinces (120 interviews). All four eastern colleges are organized similarly with a centralized provincial administration so grouping them this way maintains confidentiality. The west is more diverse, although a regional college system is present in all four provinces. (Either a group of campuses is located in a region with a central campus or urban provincial campuses control large interior areas serviced by regional campuses.) An overlapping category of northern colleges visited in various provinces is also employed, since northern colleges share some distinctive characteristics compared to southern campuses (such as major Aboriginal and industry commitments, online initiatives, and particular ways of structuring faculty teaching commitments in remote areas).

\section{Theorizing College Governance}

The split between administration and faculty visible in the national college data can be theorized as "epistemic," a term applied to disciplinary groups that adhere to particular assumptions about knowledge in their field (Knorr Cetina, 1999). In the data used for this paper, the split ran across the college equivalent of disciplines: college program areas. That is, faculty and administrators could be seen to actually carry out an "epistemic split" in implementing their differences as they went about their daily activities. How can this split be theorized? Individuals are often unaware of the epistemic assumptions that they are making in everyday interaction, which is why Glaser and Strauss' (1965) simple theory of awareness contexts provides a good starting point for exploring how college governance actually works, in the broader sense of how it is carried off.

\section{A Closed Awareness Context: Funding and the Role of Industry in College Affairs}

A closed awareness context was found to exist overall regarding funding, particularly industry-college relations. More than other areas, the topic elicited careful statements from college administrators about college-industry relations in individual interviews but unclear and divergent statements from their faculty about these arrangements, except 
where the faculty were personally involved. In this case, the researcher was like the faculty member in not being able to verify the data. An example of this lack of precise knowledge can be seen in an interview with a faculty member in Quebec who claimed that administrative secrecy was a modus operandi of CEGEP [collèges d'enseignement général et professionnel, the acronym for colleges in Quebec] administrators, whom he described as not being transparent about the total amount of funding for public colleges obtained outside of government funds. He went on to say that this secrecy was also maintained from faculty by government agencies. ${ }^{4}$

[Interviewer: Are you encouraged to have entrepreneurial activities?] Faculty Member: Yeah, what the CEGEPs have been given as candy if you will is what we call in French bonbon. Those are small diplomas...very condensed...linked to...the workplace.... They've encouraged administrations everywhere to offer their services to business and let business pay. If you need money to repair your college, well, finance it yourself.... [What percentage is raised internally? Do you have any idea? Is it 50\% or less?] No, no, I'd say it's more than that.... In the eighties, $100 \%$ was financed by the government... [I]t's hard to know because we have a Board of Administration, but they're very cautious about the way they declare how the colleges finance themselves. Usually we can know to the dime the expense of teacher salaries.... You know the pie-shaped graphics? We have a very precise share for how much the teachers are costing but...as soon as you ask questions, well, that's when they cannot answer you. It's "too complex" you know.

What is being suggested here is that the administrators are being precise about faculty salaries in order to justify faculty cuts while keeping the details of non-governmental funding away from faculty and their unions who might use these data to protect their members from being laid off. A few administrators also accused unions of protecting faculty who were incompetent and who should be fired in restructuring efforts to save money.

A second example of the closed awareness context comes from a northern college in which a faculty member in the trades expressed the view that the "majority" of funding for his college derives from selling short courses to industry or other corporate players in the North:

We have an office just down the hall here where [the teachers] only receive half their salaries from the college. The rest of it they earn through selling these courses.... The vast majority is not college credit courses, they are courses that you think people need or in consultation with advisory committees that have decided there is a need for it.

A top administrator at this college gave my colleague an account of funding sources, estimating that over $60 \%$ was governmental and that a significant commitment to Aboriginal distance education was not lucrative. To make up the difference, he suggested, "the trades can go out and contract with somebody to do a certain program." However, in reference to these contracts, he mentioned only "contracts with the Ministry for apprenticeship training" and research that might be undertaken for government and in combination with universities, not the short courses (presumably through Continuing Education or "night school") referred to by the faculty member. 


\section{The Mutual Suspicion Awareness Context: Student Success Policy}

On college websites, student success policies are promoted by administrators. Student services literature also supports these initiatives, as do faculty who are committed to the college mission of increasing access to under-represented groups. However, the data collected in this study reveals that administrators and faculty who have different views of student success policy (often around restructuring the curriculum by requiring it to be linked to specific skills and student success outcomes), engage in mutual suspicion about each other's activities. For example, administrators may be suspicious that faculty who fail their students are not as committed to equity initiatives as they should be. Meanwhile, faculty express suspicions about the goals of the student success exercise as related to funding and/or program quality and express a lack of confidence that it will "work." Faculty and administrators (along with their support staff), rather than working together transparently, often harbour strong suspicions that the activities of the other are misguided.

These student success politics involve trying ever harder to meet the goals of student success as the college student body includes more and more historically excluded groups. Awareness of the difficulties of meeting these needs is evidenced by an eastern middle manager who said, "Our population....has lower literacy rates probably than the rest of Canada.... It's the hardest work in the world because I will never do anything right.... It will never be good enough-and they're right, it won't." A top administrator at her college agreed, doubting that the intensive efforts of the middle manager to embed equity initiatives in the college would survive:

[I]n every position I've had in the past 30 years--faculty department head, dean, president-I brought an equity lens to my work. I was inside the organization [asking] how can we change that? ... In the early days of my career, I was an absolute advocate of policy-based hiring that opened the door to equity. As I aged it became readily apparent that it wasn't having the impact you think policies would have; too many ways to walk around the policy.... We always dream that this is the legacy we leave...[but] will it be there five years from now?

But a comment from a faculty member in Ontario suggests that more is going on than good intentions. This faculty member suggested that, consistent with her province's record of poor funding for colleges, administrators may be more reluctant to fail students than their teachers and teachers like herself may thus be forced to give the student the benefit of the doubt unless they have had the foresight to document student failures. She explained that if the student complains, "I was supposed to learn this and you never taught us that," then an administrator could go back to the teacher and say, "why didn't you teach that?" She commented, "It's harder to fail students because unless you track yourself and you give a student warnings saying that they have not done this component... then the administration is really reluctant to fail the student."

For their part, faculty suspected that administrators are prone not to fail the "student as client" and to keep "bums in seats" because of shortfalls in funding. One cynical western faculty member expressed an angry suspicion that administrators have abandoned standards of quality in trying to make every student a "success:" 
When I teach technology they tell me I'm quite the bastard. But that's too bad. [You're holding the standard?] Administration apparently isn't.... [You believe that administration is not holding the line on quality education?] I'm not sure where I can put that blame. They are really big on retention, but how that is interpreted is, "Well we'll keep them in and push them through." [Who pushes them through?] Sometimes marks get miraculously changed.... Every few years they go and change all the labels and we have all this work to do over.... It's the same when they decide to do a vocabulary change. All of a sudden you don't have course objectives anymore, you have course outcomes and you have to sit there and vaguely rephrase an objective into an outcome [which] none of the students actually read.

Clearly, although they may not discuss their mistrust of each other's orientations to the goals of student success, faculty and administrators are not completely comfortable with each other's motives and actions taken towards supporting it.

\section{The Mutual Pretense Awareness Context}

Two examples of mutual pretense are presented here: one involving mission change and another around workload formulas.

College Mission Change. Administrators at colleges in the south talked about changing their college mission from its traditional focus on the surrounding community to one that is more global via recruiting international students, who can study the same subjects at much less expense than at universities and transfer credit to universities. In my interviews with deans at one such college, they emphasized vigilance about making sure that their new entrepreneurial equity mission found its way "into the cracks" by carefully articulating it into budget-based policies concerning every facet of college life. The assistant to a dean present at my interview with her commented:

Just to go back to what the dean was saying about the faculty, when our team started, they very much hit resistance. Very, very much (claps hands). ...[Faculty] felt as though they already do this and they don't need anyone else. This was top-down and...it wouldn't address the issues they feel are part of equity and diversity.... But that was five years ago.... [Now the dean] and other leaders have the respect of the faculty.... There is resistance but, we believe, opportunity for growth.

A second dean at this college disagreed, arguing that faculty do not even think about these matters, a situation which gave her a free hand. She said, "In colleges, you don't have faculty taking a big stand on issues the way that they do in universities."

However, some faculty members interviewed at this college were actively enacting the original community mission according to their own training and professional commitments. They spent their own time and initiative focusing on bringing disadvantaged youth from the surroundings, which was estimated at one-third of the local communitywhat one faculty member called the "the elephant in the room." She pointed to the lack of data on the size of this population in Canada, speculating that lack of transparency around local community needs was the idea of "some very smart cookie at the top who figured this one out: you can make it difficult to deal with the data-and then it's just your word against my word." She added: 
I'm an advocate for access to literacy. So services for populations here in [local area name], in particular, because it's the immediate community. [So despite the mission statement about the global college, you are still a community college?] Yes! Hugely so, a community college.... There's differences of opinion but luckily my work continues with the community.

This coordinator proceeded to explain in detail how her area of the college was "kind of invisible" and in danger since it was pre-college and thus not "revenue generating" (i.e. not supported by government funding which is enrolment based in her province). To this point, her program had been run by funds from "foundation programs" into which students who do not qualify for their college program of choice are funneled. Like her administrators, she had to be constantly vigilant in protecting her mission because "they would like to move to the global.... In the last [few] years, [since the entrance of a new administration] there's been a dramatic change." When asked if the international focus competed with her area, she replied, "Everything competes." The previous incumbent in her position had been, she said, "Exited. I have no idea why but she was fired... They redid the department to remove her". With the new structure, even the name of the unit had been changed from "access" to "advancement". The faculty member left me with the thought that she "had a year" to show a profit before she would be closed down.

Workload Formulas. A case of mutual pretense was also discovered around the acknowledgement of faculty workload. Workload formulas exist in the most populous provinces of Ontario and Quebec, but faculty who were paid for 30 to 40 hours of work reported that they routinely worked 50 to 60 hours, without compensation for the phantom hours, allowing for the smooth operation of the institution. The number of hours paid is recorded, but faculty and administrators know that they do not reflect the actual workload of the faculty:

Quebec Faculty Member: I have at least 15 years to go, I have young kids. I can live with my salary. What I can't live with is my workload as it is right now.... More and more young teachers like me have voluntarily reduced their workload just to be able to have a somewhat normal life.... Every time the union has asked teachers to tell them how many hours you work a week, they've come up with an average of 52... I've seen teachers answering those questions and looking at the union rep and telling him, "I can tell you the truth but I'm sure no one will believe it."

[What would you say your workload was?] Ontario Faculty Member: A short week is 45 to 50 hours. I had to renegotiate because I coordinate a large program [with] a double intake...so every semester I have six courses going, and lots of students calling saying they failed so I have to custom timetable.... It's a big job. And teaching 12 hours a week on top.... On top, we don't get markers here so I do all my own marking.

Northern Faculty Member: [Our formula] doesn't reflect academic teaching loads and it certainly isn't able to reflect the differences between teaching a course where you have multiple choice testing as opposed to essay testing.... It is too numberbased.... What I was teaching during the term I don't think a week went by where I didn't take work home at least three or four times a week, especially if I had a heavy load of students. 
Administrators tended not to discuss workload issues. However, they were clearly complicit in the situation, since they arranged the contracts specifying faculty workloads.

\section{The Open Awareness Context}

Two examples of open awareness contexts involve decision-making around maintaining quality in curricula and contributions to governance by unions in their relationship to administration.

Decision Making Around Maintaining Quality in Curricula. Decision making around curricula sometimes fit the pattern of open awareness contexts, since both faculty and administrators were directly involved in carrying it out. The responses to questions about curriculum revision were mixed across curricular areas, with faculty in health professional programs emphasizing the importance of their licensing boards in ensuring faculty control over curriculum quality and content. In a previous paper (McKnight \& Muzzin, 2014), a former student and I drew from our respective data on health professional faculty to argue that we might expect a contingent (contract or part-time) faculty member who was primarily employed as a nurse or other health professional to self-identify first as a health professional and second as a college teacher. However, we also found this was the case for full-time faculty, who claimed that they and their professional licensing boards made these curricular decisions, not the dean or other administrator. In fact, they accused their deans of ignorance of their professions and its standards, and saw it as a professional duty to protect these standards against administrators who did curricular revisions without taking into account the importance of the standards. When a dean did intervene, such as in the case of changing grades assigned by the faculty member, the faculty member reported bringing pressure to bear on the administrator to come back into line with the requirements of the professional body. This is the equivalent of the patient opening up a discussion with the doctor about issues of central importance to the patient and his or her life. Health professions faculty emphasized that they were satisfied that they could handle issues of this type through vigorously defending their version of professional standards.

There remains a problem in curricular areas with weaker external bodies mandating curricula, such as the following example where an Ontario technology faculty member spoke of a struggle over this aspect of governance:

[Do you consider (the governance of your college) to be more democratic or more top-down?] Well it is a command-control style of administration. We don't reach a consensus. What I find very sad is the fact that we-and this is a very big problem in our college (you will find this out if you visit all those places you plan to). I think we have people that are in the position of say, manager, and they don't have training in applied technology. ... In the past...if you went to the nursing department, the chairperson would at least be a nurse.... Which works, they understand the curriculum.... But over the years, I think for the sake of, shall we say, saving money, they essentially have not done that. My boss, I love her, she's very good. But she doesn't know what I do.... So we have good micro-management concerning our budget lines...but for us, we'd like to have a very meaningful look through the academic lens and plan ahead.... The managers are managing in areas that are far remote from their expertise. 
A business dean at another college in Ontario argued that she, not the faculty, was the final arbiter of curriculum quality:

[Do you have bodies that faculty identify with strongly professionally?] I know that when we went from $60 \%$ course pass to $50 \%$ course pass it was the Health people who immediately came to the table and said, "Can't possibly do it.... We have all these agreements." That is one of the issues that came up around blended learning...so we would say, "Well, clearly, we have to make an exception." In Business, no.... We wouldn't have anyone stepping in and mandating to us how we would be delivering our programs.... I become the accrediting body.

In contrast to the situation of health professional faculty who feel they have control of the curriculum, there is no disagreement that administrators are in charge in the other examples given here, though the faculty member in the first example suggests that insider knowledge of the curriculum, as possessed by college teacher, is more relevant than budgeting expertise in managing the curriculum.

Contributions to Governance by Unions in their Relationship to Administration. A second case of open awareness, echoed in the literature on teaching and learning, involves significant historical and ongoing resistance to rigid conceptions of online teaching by faculty who argue that such an approach is not appropriate for students in their area for reasons of maturity, ability, motivation or the nature of the program itself. Overall, administrators and full-time faculty appear to have compromised in this area since the nuance of "blended learning" has entered the lexicon. A union president in the west cited below describes maintaining an open awareness context in which the union actively works to discourage administrators from undermining faculty control of the curriculum in various ways including forcing online teaching:

There is a huge feeling that there is a massive demand for online learning. And so there is quite a bit of pressure intermittently for us to become involved in those kinds of projects to do more in that regard.... [T] he business model and studentas-client is part of what is [pushing] people to do that... [T] he pressure is there, somewhat artificially being generated by the administration saying that there is tremendous demand and therefore you need to put courses on-line.... Because generally those courses bring back profits to the institution.... What I think the institutions tend to do, and I certainly think it happens here, is that they underestimate the investment on the part of the faculty who are teaching.... I think our faculty is fairly savvy about [that].... We think that instructors have to instruct even if they are working with electronic material that is pre-developed. And we also feel that tends to undermine the value (obviously) of the faculty members. Those are ideas that we try to keep alive I guess. I guess there is a kind of ongoing 'discussion' with administration about these kinds of things.

Open awareness contexts thus exist in particular curricular areas where faculty leverage outside professional associations to engage in open discussion with administration, and where unions support their faculty in resisting challenges to their control of the way they teach. 


\section{Discussion and Conclusion}

The goal of this paper has been to point to a new theory of college governance that is sociologically-based using symbolic interactionism (SI), which has been concerned with the classical problem of "social order," or how everyday life is accomplished (Haas \& Shaffir, 1978). The examples of closed awareness, mutual suspicion and mutual pretense identified here parallel the situation in which the physician does not openly discuss the fact that the patient is dying and does not allow him to put his affairs in order. In these examples, administrators described the situation in some detail to the researcher, while faculty interviews show a lack of awareness, puzzlement or suspicion that could not be verified or, in some cases, presentation of data indicating a contrary interpretation of affairs by the faculty member. For example, the faculty member committed to equity initiatives in the impoverished community surrounding her college has experienced the slow exclusion of her professional jurisdiction as a low-level coordinator through periodic restructuring of her work as the college appears to abandon recruiting from the local community and turns its focus to more lucrative international students. Her administrators, ironically committed to equity initiatives, have put in place an international mission-driven budgetary procedure that (perhaps unintentionally) undercuts the work of equity of the faculty member in the community, with neither party aware of the actions of the other, let alone engaged in dialogue about equity.

This particular example suggests how closed awareness, mutual suspicion and mutual pretense contexts occur. In the case of physicians and patients, patients may decide to play along because it is too difficult to "blow the whistle" without causing mayhem. In the case of the "invisible" coordinator trying to maintain the "community" mission of her college (in synchrony with similarly-invisible colleagues), she believes that making her position known (of maintaining links with the local impoverished community) might result in her being "exited" by administrators committed to recruiting international rather than local students (just as her predecessor had been "exited"). It is a basic assumption of SI that actors avoid undermining their positions, not because they are consciously resisting opposing positions, but because they are positively committed to their own positions. In other words, that is what they do, be it community outreach, enacting the curriculum according to their professional standards, or other actions. Occasionally, faculty talked about being conscious of their own appearance of compliance or of quietly resisting carrying out a policy exactly as written to ensure the smooth operation of the college as they see it. More often, they expressed confusion about why their administrators did not see things the way they did.

By way of contrast, in the first open awareness example above (sometimes characterized by participants as a "conflict" rather than "consensus" model), faculty used professional bodies outside the college to open the dialogue while in the second example, a vigilant college union attempted to maintain an open awareness context. Nationally, my research supports the observation that the closed awareness context around online learning only occurs where the college concentrates online teaching in a separate Continuing Education unit employing contingent faculty, since fulltime faculty then lose control over the process. This needs further investigation. Even in the college cited, where the union head talked about maintaining open awareness about online teaching activity, a business dean new to her job and a vice-president who were interviewed only talked about 
the positive aspects of online education, and did not seem to be aware of the union's approach. The details of the dynamics within this college were reported in an unpublished paper (Muzzin, 2011).

Symbolic interactionism does not speculate about how to promote open awareness contexts (it assumes that actors are already savvy about what can and cannot be accomplished which they decide on in situations of interaction in the moment). However, a higher education audience may hope for issues to move towards an open awareness context. Arguably patient advocacy has brought many patient-doctor interactions into an open awareness context over the past few decades and the vigorous debate over online learning in the same era has brought about a compromise between the two factions in at least some colleges. Could the same happen in the other examples presented here? For example, could the coordinator devoted to her community mission try to "stand up" to the college administration that she perceives as abandoning the founding values of the "community" college? Perhaps she could enlist the local impoverished community? SI would explain that she would not abandon her community work, essential for maintaining her position. Challenging her superiors might even be counterproductive for the community mission if she was banished from the college. However, if more persons of her persuasion could move into upper administrative positions or if unions/professional groups gave this issue more priority, there might be room to pursue both local and global (or "glocal") college missions.

As higher education scholars, we might ask in general what would be at stake if open dialogue occurred in the examples of closed awareness and mutual suspicion and pretense described above. I would venture that pretense here resembles the doctor's and the patient's historical hesitation to discuss dying which is now being discussed as part of a federal initiative for physician-assisted death and all the "inconvenient truths" this entails. Similarly, if the internal details of college fund-raising, student success policies, faculty workload, and the maintenance of quality in the curriculum were to become public, threats to the everyday operation of the college would loom, bringing into public awareness a series of possible eventualities: the slow death of (some) colleges as community institutions; the process of privatization of (some) public colleges; the exploitation of (some) faculty or (possible) lack of rigour in maintaining standards which might harm the public (e.g. through mistakes made by college graduates). All of these eventualities might damage a college's reputation which might lead to loss of public confidence in the college system itself-a result that neither faculty nor their administrators wish as they go about their daily work.

\section{Notes}

1. This phrase is taken from the project proposal, supported in part by SSHRC grant 4102006-1180. The author thanks Diane Meaghan, who conducted half of the interviews from 2006 to 2009.

2. Grounded theory methodology (GTM) has morphed into several varieties of "second generation" methodology described in Morse, Stern, Corbin, Bowers, Charmaz, \& Clarke (2009) where "second generation" leaders review new varieties of GTM including constructivist versions by Charmaz (2006) and Clarke (2009). Clarke's situational analysis (SA), employed in this project, is distinct from classical GTM in allowing inclusion of discourses such as the sociological "awareness context," and this inclusion 
of discourses in mapping is characteristic of postmodern methodology (see Lincoln, Lynham, \& Guba, 2011. p 199).

3. For example, just before and during the study period, university colleges became universities in British Columbia; a national polytechnics movement formed; and many international college campuses and partnerships emerged.

4. In these excerpts from the transcripts, the statements of the interviewer appear within square brackets. Ellipses indicate missing text.

\section{References}

Charmaz, K. (2006). Constructing grounded theory. A practical guide through qualitative analysis. Thousand Oaks, CA: Sage Publications.

Clarke, A. E. (2005). Situational analysis. Grounded theory after the postmodern turn. Thousand Oaks CA: Sage Publications.

Clarke, A.E. (2009). From grounded theory to situational analysis. What's new? Why? How? In J. Morse, P.N. Stern, J. Corbin, B. Bowers, K. Charmaz \& A. Clarke (Eds.), Developing grounded theory: The second generation. Walnut Creek CA: Left Coast Press.

Dennison, J. (Ed.) (1995). Challenge and opportunity: Canada's community colleges at the crossroads. Vancouver, BC: UBC Press.

Glaser, B. \& Strauss, A. (1965). Awareness of dying. Chicago IL: Aldine.

Glaser, B. \& Strauss, A. (1967). The discovery of grounded theory. Strategies for qualitative research. Chicago IL: Aldine.

Haas, J., \& Shaffir, W. (1978). Shaping identity in Canadian society. Toronto ON: Prentice-Hall.

Knorr Cetina, K. (1999). Epistemic cultures: How the sciences make knowledge. Boston, MA: Harvard College.

Levin, J., Kater, S., \& Wagoner, R. (2006). Community college faculty: At work in the new economy. New York, NY: Palgrave Macmillan.

Lincoln, Y., Lynham, S., \& Guba, E. (2011). Paradigmatic controversies, contradictions, and emerging confluences revisited. In N.Denzin \& Y.Lincoln (Eds.), Handbook of qualitative research. (4th ed.). (pp. 97-128). Thousand Oaks CA: Sage.

Morse, J., Stern, P.N., Corbin, J., Bowers, B., Charmaz, K. \& Clarke, A. (2009). Developing grounded theory: The second generation. Walnut Creek CA: Left Coast Press.

McKnight, K., \& Muzzin, L. (2014, Winter). 'Academic freedom' or 'bottom line': Public college healthcare professionals teaching in a global economy. College Quarterly, 17(1). Retrieved from http://collegequarterly.ca/2014-vol17-numo1-winter/mcknightmuzzin.html.

Muzzin, L. (2011, June). Academic capitalism, college-style, in Canada: A case study of the struggle for and against online learning. Paper presented at the $46^{\text {th }}$ annual conference of the Canadian Sociology Association, Fredericton NB.

Prus, R. (1987). Generic social processes: Implications for a processual theory of action for research on marketplace exchanges. Advances in Consumer Research, 14, 66-70. 


\section{Contact Information}

Linda Muzzin

Ontario Institute for Studies in Education

University of Toronto

l.muzzin@utoronto.ca

Linda Muzzin is associate professor in the Higher Education program at the Ontario Institute for Studies in Education of the University of Toronto, where she teaches graduate courses on education and professions, the professoriate, theory, and research methods. Recent research and writing include a review of professors and professionalism in the academy for a Routledge handbook on professions; articles on professorial identity cowritten with Tina Martimianakis; and research on college instructors and equity. 